\title{
Analisis Tingkat Kesadaran Penggunaan Free/Open Source Software (FOSS) pada Lembaga Pendidikan Indonesia
}

\author{
Daniel Arsa ${ }^{1}$, Hafiz Nugraha ${ }^{2}$ \\ ${ }^{1}$ Fakultas Sains dan Teknologi, Universitas Jambi \\ email: danielarsa@unja.ac.id \\ ${ }^{2}$ Fakultas Sains dan Teknologi, Universitas Muhammadiyah Jambi \\ email: nugrahahafiz82@gmail.com
}

\begin{abstract}
In this paper, the authors conducted small-scale research to determine the awareness, utilization, and barriers of school teachers, especially for Information and Communication Technology (ICT) teachers in using Free and Open Source Software (FOSS). In Indonesia, the utilization of applications and operating systems in educational institutions are still dependent on popular software, it makes the process of learning in schools often mentions the names or brands of certain software that are often used and are usually proprietary. In recent years, several parties have started the Free and Open Source Software (FOSS) movement to break the notion of using Proprietary software, FOSS is starting to be seen by users because of it's affordability and freedom to use and contribute to developing software together. There are many FOSS that is often used such as Ubuntu, Mozilla Firefox, Moodle, OJS, and many more. The Indonesian government also encourages the use of FOSS in some institutions that have been introduced to FOSS. in this research, the author uses a quantitative approach with a descriptive survey method, it takes a sample from a population and uses a questionnaire as the main data aid. As a result, many obstacles were found that made teachers and students reluctant to use FOSS in their education, such as lack of knowledge, lack of training, availability of technology, and awareness of it.
\end{abstract}

\section{Keywords: FOSS, ICT, Proprietary software, Education}

\section{PENDAhUluan}

Transformasi digital memungkinkan guru dapat mengemas dan menyampaikan ilmu pengetahuan dengan berbagai cara. Guru dapat mengembangkan teknik dan model pembelajaran, pemberian tugas, penilaian, bahkan menerapkannya menggunakan Learning Management System sehingga proses belajar-mengajar berlangsung secara interaktif dan tanpa batas. Akan tetapi, perangkat lunak dan tools yang terbiasa digunakan menyerap dana yang besar, terutama pada aspek sistem operasi dan perangkat lunak pendukung sehingga sebagian besar sekolah menggunakan produk bajakan.

Kesalahan kegiatan belajar mengajar selama ini adalah guru sering mengenalkan produk (merek) bukan subtansi. Guru mengenalkan Windows, bukan mengenalkan sistem operasi. Apabila guru bisa mengajarkan substansi maka dunia pendidikan akan sadar bahwa kebiasaan menggunakan perangkat lunak berpemilik (proprietary) akan menciptakan ketergantungan.

Free Open Source Software (FOSS) bertujuan untuk mendobrak batasan ini. Menurut Free Software Foundation berarti pengguna perangkat lunak memiliki kebebasan untuk menggunakan dan memodifikasinya. hal ini mendorong dan memungkinkan distribusi ketersediaan perangkat lunak secara gratis di dalam sebuah komunitas atau organisasi. Lisensi produk FOSS memungkinkan pengguna untuk menggunakan, mempelajari, memodifikasi, dan/atau menyebarkan perangkat lunak FOSS secara bebas (Free Open Source Foundation 2014). Keuntungannya adalah setiap komunitas atau organisasi yang menggunakan memiliki hak untuk mengembangkan FOSS sesuai kebutuhannya sendiri tanpa perlu membayar biaya lisensi (Putratama dan Ali 2020).

Manfaat FOSS tidak hanya memanfaatkan perangkat lunak secara gratis, tetapi juga berbagi sumber daya, perbaikan kode dengan cepat, kualitas source code yang 
mumpuni, memanfaatkan sumber daya bersama untuk pengembangan dan pemeliharaan, dan memberdayakan end-user untuk mendapatkan semua manfaat dari menggunakan produk FOSS.

Salah satu sektor bisnis yang mendapatkan keuntungan besar dari Free and Open Source Software (FOSS) adalah sektor pendidikan (Gangadharan and Butler 2012). Dalam platform FOSS tersedia berbagai aplikasi yang memiliki fungsi serupa seperti yang dikembangkan platform proprietary. Untuk aplikasi perkantoran tersedia Libre Office; untuk aplikasi grafis ada GIMP, Inkscape, dan Scribus; aplikasi audio-video ada XMMS, Audacity, Audacious, Amarok, Kafeein; untuk animasi ada Blender; untuk browser ada firefox; Untuk aplikasi pendidikan kita bisa menggunakan Stellarium untuk pelajaran perbintangan atau astronomis, moodle untuk learning management system serta ada banyak distbusi Linux yang dapat digunakan sebagai sistem operasi.

Di luar keunggulan yang telah disebutkan, adopsi produk FOSS tidak lepas dari kendala. Secara umum, hambatan tersebut meliputi (1)Biaya migrasi dan operasi, (2)kekurangan sumber daya; (3)kepuasan dengan produk perangkat lunak yang ada; (4)faktor manusia seperti pengguna yang skeptis atau resisten terhadap perubahan; (5)ketidaksesuaian perangkat keras; (6)kurangnya informasi produk FOSS; (7)kurangnya pengetahuan kasus tentang keberhasilan adopsi FOSS oleh organisasi serupa; (8)birokrasi dalam pengambilan keputusan TIK (Putratama dan Ali 2020).

Dalam artikel ini, penulis melakukan penelitian skala kecil untuk mengetahui kesadaran, pemanfaatan, dan hambatan guru sekolah khususnya bagi guru Teknologi Informasi dan Komunikasi (TIK) dalam menggunakan Free and Open Source Software (FOSS). Penulis menggunakan pendekatan kuantitatif dengan metode survei deskriptif, pengambilan sampel dari suatu populasi dan menggunakan kuesioner sebagai bantuan data utama.

\section{Tinjauan Pustaka}

Setiap penelitian harus dilakukan atas dasar beberapa kebutuhan dan untuk ini, tinjauan pustaka yang dilakukan oleh peneliti dianalisis. (Johnston dkk. 2013) menemukan bahwa faktor-faktor kunci yang menghalangi penerapan FOSS di sekolah yaitu kurangnya Compatibility produk FOSS dengan proprietary software, kurangnya sumber daya manusia terlatih, penolakan staf TI, kurangnya dukungan manajemen, kurangnya kebijakan yang jelas, dan sikap individu yang negatif. Mereka juga menemukan bahwa semua responden menggunakan produk Microsoft setiap hari meskipun mereka mengetahui tentang FOSS.

(Blessing 2012) juga menemukan dalam studinya bahwa sebagian besar pustakawan di Nigeria memiliki sedikit kesadaran mengenai ketersediaan FOSS dan sehingga tidak menggunakan FOSS secara signifikan dalam pengelolaan organisasinya. faktor lainnya adalah masih kurangnnya keterampilan TIK yang diperlukan untuk mempermudah adopsi dan pemanfaatan FOSS.

Dalam sistem pendidikan sekolah diperkirakan silabus tidak memiliki komponen FOSS, kesadaran guru tentang hal ini sangat kurang. ketidaktersediaan dan sikap terhadap FOSS juga merupakan salah satu faktor utama. (Woodall dan Marius 2013) menemukan bahwa sebagian besar negara dan institusi tidak memiliki kebijakan resmi tentang FOSS dan hanya beberapa tingkat penggunaan FOSS yang terlihat di setiap negara. Saini melakukan penelitian tentang FOSS dan menemukan bahwa lembaga pendidikan dan organisasi penelitian memiliki tingkat penggunaan dan pengadopsian FOSS yang sangat rendah (Deepty dan Surbhi 2018). Ia juga menemukan bahwa sangat sedikit program studi yang mengembangkan repository FOSS yaitu sebanyak 25\% dan mayoritas program studi tidak menanamkan budaya memiliki, mengembangkan, dan mengembangkan repository FOSS pada masing-masing institusinya.

\section{Implementasi FOSS di Dunia}

Banyak negara di dunia dan sistem pendidikan mereka telah mengadopsi FOSS. Beberapa negara dengan status penggunaan FOSS diberikan di bawah ini:

Eropa telah menjadi pusat dari sejumlah besar pengembang dan proyek FOSS Lisensi Publik Uni Eropa (EUPL) membuka jalan ke fondasi banyak platform komunitas yang 
mendukung pengembangan FOSS, misalnya, Open Source Observatory and Repository (OSOR.eu) adalah inisiatif pemenang penghargaan yang menawarkan seperangkat alat Web 2.0 FOSS yang direkomendasikan yang digunakan untuk kolaborasi sosial.

Dengan $12,4 \%$ pengembang FOSS berasal dari Jerman, peringkat kedua di dunia setelah Prancis dalam hal kewarganegaraan pengembang/kontributor FOSS. Bundestag adalah badan legislatif di Jerman, yang menggunakan Linux pada 150 server-nya.

Dengan 16,5\%, jumlah terbesar dari pengembang FOSS adalah Perancis dan rumah-rumah Perancis memiliki 15,4\% dari pengembang FOSS dunia.

Spanyol adalah salah satu pengadopsi perangkat lunak open source tercepat di Eropa karena pemerintahnya memiliki kebijakan pro FOSS dan memiliki banyak proyek FOSS utama untuk mendukung kebijakan ini. Sejak 2002 di Spanyol, Negara Bagian Extremadura telah menyebarkan lebih dari 80.000 salinan LinEx (versi Debian yang dikembangkan secara lokal) ke sekolahsekolah (Deepty And Surbhi, 2018).

Pada 27 Desember 2010, Vladimir Putin, Presiden Rusia mengeluarkan perintah agar pemerintah Rusia beralih ke open source.

Banyak universitas di seluruh dunia telah mulai mempromosikan FOSS dalam pendidikan mereka dan Universitas Terbuka Catalonia memulai Master Internasional pertama di bidang open source software.

Di Amerika Latin, Brasil terdepan dalam penggunaan, adopsi dan kontribusi FOSS. Pendaftaran Universitas dilakukan melalui Internet berbasis open source. EProinfo adalah proyek e-learning yang telah melatih 50.000 siswa di Brasil. EProinfo adalah perangkat lunak publik yang dikembangkan untuk Sekretariat Pendidikan Jarak Jauh dan dirilis di bawah lisensi GPL.

Distribusi GNU/Linux Cina yang disebut Red Flag Linux adalah inisiatif pemerintah, yang bertujuan untuk mengembangkan industri sumber terbuka Cina (Deepty And Surbhi, 2018).
FOSS telah hadir dalam kebijakan pemerintah Afrika Selatan sejak tahun 2007. Beberapa inisiatif dan proyek yang menggunakan FOSS adalah FOSSFA, ict@innovation, OSISA, AVIOR, ANLoc, OER Africa, dan AITI-KACE.

Di beberapa negara seperti Cina, Jepang, dan Korea Selatan, kolaborasi dilakukan oleh komunitas FOSS untuk menantang produk Microsoft yang digunakan di sekolah (Shaame, 2014).

\section{METODE PENELITIAN}

Pada penelitian ini penulis menggunakan metode survei deskriptif untuk pengumpulan data. Penelitian survei termasuk ke dalam penelitian yang bersifat kuantitatif untuk meneliti perilaku suatu individu atau kelompok. Pada umumnya penelitian survei menggunakan kuesioner sebagai alat pengambil data. Penelitian survei adalah penelitian yang mengambil sampel dari satu populasi dan menggunakan kuesioner sebagai alat pengumpulan data yang pokok. Metode survei ini sangat popular dan banyak digunakan dalam penelitian karena cepat dan mudah untuk dilaksanakan (Hasibuan 2007). Pada gambar 1. merupakan kerangka kerja pelaksanaan penelitian yang menggunakan metode survei.

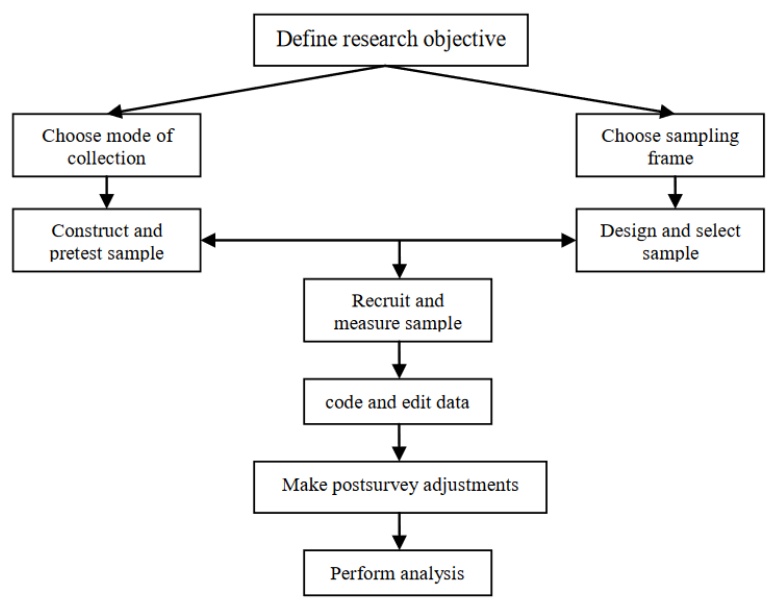

Gambar 1. Kerangka Kerja Penelitian metode survei (Groves, 2010)

Kuesioner merupakan instrumen utama yang digunakan untuk pengumpulan data. Kuesioner yang dikembangkan dibagi menjadi empat bagian. Bagian pertama memperoleh informasi tentang latar belakang 
responden dengan pertanyaan seperti nama, asal sekolah, jabatan, lama bekerja, kualifikasi pendidikan, jenis kelamin dan status kepegawaian. Bagian kedua mengeksplorasi informasi tentang kesadaran akan keberadaan FOSS sementara Bagian ketiga berisi penggunaan perangkat lunak ini di proses pembelajaran. Bagian keempat berisi identifikasi hambatan pemanfaatan FOSS pada pelaksanaan pendidikan secara keseluruhan. Data yang terkumpul akan dianalisis statistik deskriptif dengan menggunakan perhitungan persentase dan frekuensi.

\section{HASIL DAN PEMBAHASAN}

Kuesioner dalam bentuk google form didistribusikan kepada 50 responden namun hanya sebanyak empat puluh dua (42) yang mengisi kuesioner sampai selesai. Setelah diperiksa, empat puluh dua (42) kuesioner mewakili 25 sekolah negeri maupun swasta yang terdapat di kota Sungai Penuh. Data yang terkumpul akan dianalisis statistik deskriptif dengan menggunakan hitungan persentase dan frekuensi.

\section{Kesadaran dan Pemanfaatan FOSS}

Untuk memastikan tingkat kesadaran dan ketersediaan FOSS, responden diminta untuk menjawab pertanyaan mengenai awareness, fungsionalitas, dan availability dari sembilan belas (19) produk FOSS pada masing-masing responden. Tanggapan yang dihasilkan dapat dilihat pada tabel 1. Hasil penelitian menunjukkan bahwa lebih dari 90\% responden menyatakan mereka sama sekali tidak mengetahui tersedianya 10 dari 19 produk FOSS yang disebutkan, meliputi; Moodle, GeoGebra, Kazam Screencaster, Stellarium, Audacity, LibreOffice, VLC, Pencil, GCompris, Scratch. Firefox dan OBS mendapatkan nilai kesadaran dan ketersediaan tertinggi dengan masing-masing persentase 93 $\%$ dan $29 \%$. sedangkan dua produk FOSS, BigBlueButton dan Scratch mendapatkan persentase terendah disetiap atribut yang diberikan yaitu $0 \%$. Dari ketiga aspek awareness, availability, dan pengetahuan fungsionalitas produk FOSS, hanya ada satu produk FOSS (firefox) yang mendapatkan persentase lebih dari $50 \%$.

Tabel 1. Tanggapan atas kesadaran dan ketersediaan FOSS

\begin{tabular}{|c|c|c|c|c|c|c|c|c|c|}
\hline \multirow[t]{2}{*}{$\begin{array}{l}\text { Open Source } \\
\text { Software }\end{array}$} & \multicolumn{2}{|c|}{$\begin{array}{c}\text { Tahu } \\
\text { Perangkat } \\
\text { lunak } \\
\text { tersedia }\end{array}$} & \multicolumn{2}{|c|}{$\begin{array}{c}\text { Tahu } \\
\text { kegunaan }\end{array}$} & \multicolumn{2}{|c|}{$\begin{array}{c}\text { Tersedia di } \\
\text { Komputer/ } \\
\text { Lab }\end{array}$} & \multicolumn{3}{|c|}{$\begin{array}{c}\text { Tidak } \\
\text { Tahu } \\
\text { Perangkat } \\
\text { Lunak } \\
\text { tersedia }\end{array}$} \\
\hline & $\mathrm{F}$ & $\%$ & $\mathrm{~F}$ & $\%$ & $\mathrm{~F}$ & $\%$ & $\mathrm{~F}$ & & $\%$ \\
\hline BigBlueButton & - & & & & - & . & - & & 100 \\
\hline Moodle & 2 & 5 & 5 & 5 & 5 & - & - & 40 & 95 \\
\hline Ubuntu & 5 & 12 & 2 & 12 & 2 & - & - & 37 & 88 \\
\hline GeoGebra & 1 & 2 & 2 & 2 & 2 & - & - & +1 & 98 \\
\hline $\begin{array}{l}\text { Kazam } \\
\text { Screencaster }\end{array}$ & 1 & 2 & 2 & & 1 & 2 & 2 & 41 & 98 \\
\hline Stellarium & 2 & 5 & 5 & 5 & 1 & 2 & 2 & 40 & 95 \\
\hline Audacity & 3 & 7 & 7 & 7 & 2 & 5 & 5 & 39 & 93 \\
\hline LibreOffice & 2 & 5 & 5 & 10 & 1 & 2 & 2 & 40 & 95 \\
\hline Blender & 6 & 14 & 4 & 12 & 2 & 5 & 5 & 36 & 86 \\
\hline GIMP & 6 & 14 & 4 & 12 & 2 & 5 & 5 & 36 & 86 \\
\hline VLC & 6 & 14 & 4 & 14 & 3 & 7 & 7 & 36 & 86 \\
\hline Pencil & 3 & 7 & 7 & 7 & 1 & 2 & 2 & 39 & 93 \\
\hline GCompris & 2 & 5 & 5 & 5 & 5 & - & - & 10 & 95 \\
\hline Firefox & 39 & 93 & $3 r$ & 71 & 25 & 60 & & 3 & 7 \\
\hline Inkscape & 6 & 14 & 4 & 14 & 3 & 7 & 7 & 36 & 86 \\
\hline OBS & 12 & 29 & 12 & 29 & 5 & 12 & 2 & 30 & 71 \\
\hline OpenShot & 5 & 12 & 2 & 12 & 3 & 7 & 7 & 37 & 88 \\
\hline Python & 7 & 17 & 7 & 17 & 3 & 7 & 7 & 35 & 83 \\
\hline Scratch & - & - & - & . & - & - & - & - & 100 \\
\hline
\end{tabular}

\section{Hambatan Pemanfaatan FOSS pada Bidang Pendidikan}

Untuk mengetahui alasan mengapa sebagian besar guru belum menggunaan FOSS pada proses pembelajarannya, peneliti meminta responden untuk mengidentifikasi faktor-faktor yang menyebabkan non-utilisasi produk FOSS. Hasil tanggapan diperlihatkan pada tabel 2.

Tabel 1. Tanggapan atas hambatan pemanfaatan FOSS pada pelaksanaan pendidikan

\begin{tabular}{lllllll}
\multirow{2}{*}{ Atribut } & \multicolumn{2}{c}{ Ya } & \multicolumn{2}{c}{ Tidak } & \multicolumn{2}{c}{ Ragu-ragu } \\
\cline { 2 - 6 } & F & $\%$ & F & $\%$ & F & $\%$
\end{tabular}




\begin{tabular}{llllll}
\hline $\begin{array}{l}\text { Tidak tersedia tenaga } \\
\text { terampil yang } \\
\text { memahami FOSS }\end{array}$ & 1023.8 & 25 & 59.5 & 7 & 16.7 \\
\hline $\begin{array}{l}\text { Kurangnya pengetahuan } \\
\text { tentang bagaimana } \\
\text { menggunakannya } \\
\text { produk FOSS }\end{array}$ & 1023.8 & 23 & 54.8 & 9 & 21.4 \\
\hline $\begin{array}{l}\text { Tidak adanya } \\
\text { ketentuan/aturan/kurikul } \\
\text { um yang mengharuskan } \\
\text { untuk menggunakan }\end{array}$ & 2559.5 & 9 & 21.4 & 8 & 19.0 \\
\hline
\end{tabular}

Pimpinan tidak melihat manfaat yang relevan

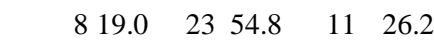
Produk FOSS

\begin{tabular}{lllllll}
\hline $\begin{array}{l}\text { Kurangnya kesadaran } \\
\text { eksistensi produk FOSS }\end{array}$ & 2252.4 & 12 & 28.6 & 8 & 19.0 \\
\hline $\begin{array}{l}\text { Tidak tersedianya akses } \\
\begin{array}{l}\text { internet di lingkungan } \\
\text { sekolah }\end{array}\end{array}$ & 2354.8 & 18 & 42.9 & 1 & 2.4 \\
\hline
\end{tabular}

kawatir akan kurangnya $\begin{array}{llllll}\text { referensi solusi jika } & 2764.3 & 6 & 14.3 & 9 & 21.4\end{array}$ software bermasalah

\begin{tabular}{llllll}
\hline Kawatir tidak adanya & 3071.4 & 3 & 7.1 & 9 & 21.4
\end{tabular}
update terbaru

$F=$ Frekuensi, $\%=$ persentase

Dari data yang didapatkan, 54,8\% responden menyatakan bahwa masalah mereka berkaitan dengan tidak tersedianya akses Internet, 42,9\% tidak bermasalah dengan ketersediaan akses internet. 71,4\% responden menyatakan kawatir tidak adanya update terbaru dari software, $64,3 \%$ menjawab kawatir akan kurangnya referensi solusi jika software bermasalah dan 23,8\% responden menjawab keterampilan TIK yang terampil diperlukan untuk adopsi dan pemanfaatan perangkat lunak FOSS, sementara kurangnya kesadaran tentang keberadaan perangkat lunak diakui oleh 52,4 $\%$ dari seluruh populasi.

Selain itu, Kurangnya pengetahuan tentang bagaimana menggunakannya produk FOSS dianggap oleh 23,8 \% responden sebagai hambatan yang berkaitan, sejalan dengan $59,5 \%$ responden yang juga menganggap tidak adanya ketentuan/aturan/ kurikulum yang mengikat membuat guru tidak memanfaatkan produk-produk FOSS.

\section{KESIMPULAN}

Dari hasil penelitian ini dapat menjelaskan bahwa pengadopsian FOSS memberikan kebebasan bagi pengguna untuk menggunakan source code, membuat salinan, dan mendistribusikan perangkat lunak kepada orang lain sehingga dapat menghemat anggaran dalam pengadaan perangkat lunak dan menghindari penggunaan perangkat lunak bajakan. Ada banyak perangkat lunak Free Open Source yang digunakan dalam dunia pendidikan dan memiliki fungsionalitas yang hampir sama dengan perangkat lunak proprietary. Melalui penelitian ini dapat disimpulkan bahwa kesadaran tentang FOSS di kalangan guru sekolah masih sangat kurang dan mayoritas masih menggunakan perangkat lunak proprietary untuk kebutuhan mengajar dan proses pembelajarannya. Beberapa hambatan utama untuk mengadopsi FOSS yang disebutkan oleh guru adalah Tidak adanya ketentuan/aturan/kurikulum yang mengharuskan untuk menggunakan, kurangnya kesadaran umum tentang FOSS; kekawatiran akan kurangnya referensi dan dukungan jika software bermasalah; tidak ada pelatihan yang diberikan kepada mereka dan kurangnya dukungan teknis. Mereka memiliki persepsi positif terhadap penggunaan FOSS, tetapi hambatan harus dihilangkan untuk kemudahan adopsi.

\section{REFERENSI}

Blessing, Ukachi Ngozi. 2012. "Awareness, Availability and Utilization of Open Source Software in Nigerian Libraries: The Way Forward.” International Research Journal of Library, Information and Archival Studies 1(1): 01-09.

Deepty, Gupta, And Surbhi. 2018. “Adopting Free And Open Source Software (Foss) In Education." i-Manager's Journal of Educational Technology 14(4): 53. http://www.imanagerpublications.com/a rticle/13979.

Foundation, Free Software. 2014. "The Free Software Foundation." Free Software Foundation.

Gangadharan, G. R., and Martin Butler. 2012. "Free and Open Source Software Adoption in Emerging Markets: An Empirical Study in the Education Sector." In IFIP Advances in Information and Communication Technology, , 244-49.

Groves,Robert M.,Survey 
Vol.3 No.1, Agustus 2020

Methodology(2010),Second edition of the (2004) first edition ISBN0-47148348-6

Hasibuan, Zainal A. 2007. "Metodologi Penelitian Pada Bidang Ilmu Komputer Dan Teknologi Informasi." Konsep, Teknik, Dan Aplikasi.

Johnston, Kevin, Shameemah Begg, and Maureen Tanner. 2013. "Exploring the Factors Influencing the Adoption of Open Source Software in Western Cape Schools." International Journal of Education and Development using Information and Communication Technology 9(2): 64-84.

Putratama, Surya Handika, and Syaiful Ali. 2020. "Adopsi Produk Free/Open Source Software Di Industri Jasa Pelayanan Kesehatan: Studi Kasus Indonesia.” Jurnal Reviu Akuntansi dan Keuangan 10(1): 161-76.

Woodall, Lora, and Michele Marius. 2013.

"Free and Open Source Software, Open Data, and Open Standards in the Caribbean : Situation Review and Recommendations." (August): 76. http://www.unesco.org/openaccess/terms-use-ccbysa-en. 